Original Research

\title{
Triggered Recurrence Factors of Mental Illness Patients in an Emergency Unit in a Psychiatric Hospital
}

\section{Selvya Hesti Andriyani, Ana Oktarisa and Arum Pratiwi}

Faculty of Health Science, Universitas Muhammadiyah Surakarta, Solo, Indonesia

\begin{abstract}
Introduction: Understanding the trigger recurrence factors of mental illness patients is important because the number of mental hospital visits has been increasing every year, especially in mental illness patients who have experienced recurrence. This research aimed to identify and describe some of the types of trigger that result in recurrent readmission to the emergency unit of a psychiatric hospital.
\end{abstract}

Methods: The study was designed using a quantitative method with a univariate and bivariate analysis approach using a cross-sectional design. The researcher conducted the study in the Emergency ward of Surakarta mental hospital for 2 months and obtained 71 total samples on patient readmission where there was a recurrent mental illness. The samples were taken using the accidental sampling technique. The data was taken using a questionnaire and analyzed using narrative description and central tendencies.

Results: The results showed that the highest trigger recurrence factors were 58\% related to patient compliance when taking medication. The results showed that there are various triggers for the recurrence of mental illness.

Conclusion: These were evidenced by the family members who stated that they found the medication around the house or in the patient's shirt pocket. The other trigger recurrence factors which were categorized as less influential were family support and the environment of society, which were $4 \%$.

\section{ARTICLE HISTORY}

Received: Dec 26, 2019

Accepted: Dec 31, 2019

\section{KEYWORDS}

mental illness; medication; trigger recurrence factors

\section{CONTACT}

Selvya Hesti Andriyani $\triangle \llbracket 210164004 @$ student.ums.ac.id

$\Xi^{\prime}$ Faculty of Health Science, Universitas Muhammadiyah Surakarta, Solo, Indonesia

Cite this as: Andriyani, S. H., Oktarisa, A., \& Pratiwi, A. (2019). Triggered Recurrence Factors of Mental Illness Patients in an Emergency Unit in a Psychiatric Hospital. Jurnal Ners, 14(3si), 21-25. doi:http://dx.doi.org/10.20473/jn.v14i3(si).16955

\section{INTRODUCTION}

According to the Indonesian Big Dictionary, being healthy is a state where the whole body feels fit and comfortable. This feeling of being fit and comfortable is relative because it differs according to people who interpret those feelings (Yusuf, PK, \& Nirhayati, 2017). Clausen defines healthy people as people who can prevent mental disorders that are due to various stressors and that are influenced by the size of the stressors, in addition to religion, culture, beliefs, meanings etc (Yusuf et al., 2017).

Psychological factor has a great impact on someone mental health. According to Law Number 18 2014 concerning mental health, mental health is a condition where a person can develop physically, mentally, spiritually and socially so then the person is aware of his own abilities, so then they can overcome stress, so then they can work productively and so they are able to contribute to their environment. Ironically, mental health is still one of the most common health problems in the world, including in Indonesia. On the other hand, when someone has a mental illness, it means that they are experiencing disorders in terms of their behavior, thoughts, and feelings that are manifested in the form of a set of symptoms and/or behavioral changes that are meaningful, and that can cause obstacles and suffering when they are carrying out their functions as humans(Indonesian Ministry of Health, 2014).

According to WHO data (2016), there are around 60 million people affected by bipolar disorder, 47.5 
million people affected by dementia, 35 million people affected by depression and 21 million people affected by schizophrenia in the world. The 2013 Riskesdas data showed that mental-emotional disorder are indicated by symptoms of anxiety and depression in people aged 15 years and over reaching around 14 million people $(6 \%)$ of the total population of Indonesia. The incidence of severe mental disorders such as schizophrenia reached around 400,000 people or as many as 1.7 per 1,000 population(Indonesian Ministry of Health, 2016).

These numbers are very concerning. When the number of people who have mental illness increases, this means that people's well-being has decreased while their stress level has increased. This is because mental disorders can occur due to precipitating factors, which then trigger the factors that will later cause emotional stress or the appearance of stress. If this emotional pressure is experienced by someone who has low coping, then this will cause someone to experience mental disorders (Kanel, 2015). Therefore, the trigger or the cause's factors that cause the patient to have mental illness were various.

The data from the Central Java Provincial Health Office shows that the number of mental patients has increased. In 2015, there were 317,504 people who visited with mental disorders with the largest percentage of visits being in hospitals, at 60.59 percent. In 2016, the number of visits to hospitals due to mental disorders was 413,612 people with the largest percentage of visits to psychiatric patients in hospitals being 68.33 percent (Ministry of Health, n.d.). Based on data from the Regional Mental Hospital Dr. Arif Zainudin Surakarta, the number of mental patients in 2015 was 3,298 people and this increased in 2016 to 3,394 people. A large number of patients with mental disorders were not new patients experiencing mental disorders. There were also mental patients experiencing recurrence (Surakarta Mental Hospital, 2017).

Recurrence in mental patients occurs because of the appearance of the same symptoms as before. The frequency of recurrence is the period of times when the previous symptoms experienced by the client reappear and cause those with a mental disorder to need to be treated again (Kelliat, 2011). A preliminary study conducted by the researcher in the Surakarta Regional Mental Hospital in the Emergency Room in May 2018 was where the data was obtained that when the patient comes into the emergency room, the nurse asked the patient or the family of the patient about several things, namely when they had their last treatment, what medication the patient consumed, when they were last in control, and the symptoms experienced by the patient that caused the patient to relapse and be taken to a mental hospital. There were many causes of patient recurrence but we did not examine the cause of the patient's recurrence, as the study only examined the symptoms that caused the patient to be taken to a mental hospital. From the phenomena above, the researcher became interested in conducting research on the triggered recurrence factors of mental illness patients in the Emergency Unit of a Psychiatric Hospital.

\section{MATERIALS AND METHODS}

The research design was quantitative and descriptive with a cross-sectional design approach. This research was done between July and August 2018 in the Emergency ward of Surakarta mental hospital. The total sample involved consisted of 71 mental illness patients in the Emergency ward taken through accidental sampling technique. This research used a single variable. The variable was the triggering recurrence factors of the mental illness patients. The instruments that were used were the components required to examine the patients in the emergency room, including patient identity, the history of the current disease, the trigger factors for the recurrence of patients while in the emergency room and the frequency of patient recurrence in the past year.

Furthermore, the other instrument was a Guttman scale questionnaire which consisted of yes or no answers. This instrument was used to identify the causes of relapse of mental disorders in order to determine the classification of the patients who were studied to discuss the findings from the patient's history, where the instrument was chosen accordingly. Later on, the data was analyzed using the univariate and bivariate methods.

\section{RESULTS}

In this research study, the respondents consisted of 71 mental illness patients who came to the Emergency unit of Surakarta mental hospital. Furthermore, the table below (Table1) describes the characteristics of the respondents based on their age, gender, education level and occupation. Table 1 showed that for mental illness, $63 \%$ of the patients who came to the emergency ward were in the productive age range between 25-35 years old. Based on gender, there were more male than female patients, which reached up to $58 \%$. Furthermore, the mental illness patients who had an educational background of senior high school had the top percentage $(42 \%)$ above the other educational backgrounds. Even though most of them were welleducated, according to the occupation survey, most of the patients did not work to meet their daily needs. This means that other family members are the ones who work to meet the family needs.

Based on the frequency distribution table for patient recurrence, it was found that the majority of patients who experienced recurrence in the category of infrequent relapse were $62 \%$, which means that they were readmitted 2 times or less a year. On the other hand, there were $38 \%$ categorized in the frequent recurrence category, which means that they were readmitted 3 times or more in a year. Based on Table 2, focused on the distribution of patient recurrence, it was found that the majority of patients 
Table 1. Characteristic respondents $(n=71)$

\begin{tabular}{|c|c|c|}
\hline Characteristics of respondents & $\mathbf{n}$ & $\%$ \\
\hline \multicolumn{3}{|l|}{ Ages: } \\
\hline 25 - 35 years old & 45 & 63 \\
\hline $36-45$ years old & 16 & 23 \\
\hline $46-55$ years old & 6 & 9 \\
\hline $56-65$ years old & 3 & 4 \\
\hline 76 - 85 years old & 1 & 1 \\
\hline \multicolumn{3}{|l|}{ Gender: } \\
\hline Male & 41 & 58 \\
\hline Female & 30 & 42 \\
\hline \multicolumn{3}{|l|}{ Education Level: } \\
\hline Elementary School & 21 & 30 \\
\hline Junior High School & 19 & 27 \\
\hline Senior High School & 30 & 42 \\
\hline University/college & 1 & 1 \\
\hline \multicolumn{3}{|l|}{ Occupation: } \\
\hline Does not work & 61 & 86 \\
\hline Private sector worker & 3 & 4 \\
\hline Entrepreneur & 6 & 9 \\
\hline Labourer & 1 & 1 \\
\hline
\end{tabular}

Table 2. Frequency Distribution of Patient Recurrence $(n=71)$

\begin{tabular}{lcc}
\hline Frequency of Recurrence in a Year & $\mathbf{n}$ & $\mathbf{\%}$ \\
\hline Rarely relapse $(<2 \mathrm{x})$ & 44 & 62 \\
Relapse often $(>3 \mathrm{x})$ & 27 & 38 \\
\hline
\end{tabular}

who experienced recurrence in the category of infrequent relapse made up $62 \%$, which means that they were readmitted 2 times or less in a year. On the other hand, there were $38 \%$ categorized in the frequent recurrence category, which means that they were readmitted 3 times or more in a year.

Based on Table 3, it can be seen that there were some trigger factors which lead the patients to the recurrence of their mental illness. The first factor was the patient's compliance when it came to taking their medication. Most of them were not taking their medications routinely. These cases were evidenced by $58 \%$ of them throwing their drugs around the house or keeping the drugs in their pocket. The percentage of patients who irregularly took their medication was $56 \%$.

The next factor was the utilization of health facilities. For this factor, it showed that $49 \%$ of them were rarely in control of the health facilities, while the rest $(24 \%)$ were rejected when it came to handing control over to the health facilities. The third was family support. In this section, 31\% of the patient's families were locking up the patients at home. Furthermore, most of them also did not take the time to communicate with the patients. In those cases, the patients might feel abandoned. It could also make the patients become isolated and feel that there is a lack of family support, which could increase their stress and make their mental illness recur.

The last trigger factor came from the community environment. This factor indicated how society supports the patients with mental illness. The result showed that $42 \%$ of society preferred to avoid the patients when they cross paths; $38 \%$ of society also felt that the patients were disturbing the community.
This means that most of the people surrounding where the patients lived did not support them.

Based on the table above, it can be explained that the strength of the influence of the patient compliance factors in taking their medication, the utilization of health facilities and family support with the frequency of frequent recurrence were obtained as follows:

$$
\begin{gathered}
y=2,197-2,610(\text { kep_minum_obat })-2,736(\text { duk_kel })^{+0,408(\text { pem_faskes })} \\
y=2,197-2,610(0)-2,736(0)+0,408(0) \\
y=2,197 \\
\text { Thus, the probability is: } \\
p=1 /(1+\text { ey })=1 /(1+2.7(2,197))=1 / 1+8.865=1 \\
/ 9.865=0.101
\end{gathered}
$$

Thus, the probability of recurrence in the patients suffering from mental disorders is $10.1 \%$. Based on the above equation, the conclusions are as follows: 1) The probability of patient recurrence is $10.1 \%$, which means that when medication compliance, family support and the utilization of health facilities is constant $(=0)$, then the patient's recurrence rate is 10 times. 2) The logistic regression coefficient patient compliance factor for taking their medicine was $-2,610$, which means that per increase alongside one unit of medication compliance, the recurrence rate drops by 2,610 units. 3) The logistic regression coefficient of the family support factor is 2.736, which means that an increase in one unit of medication compliance follows a recurrence rate of 2.736 units. 4) The logistic regression coefficient of the utilization of health facilities was 0.408 , which means that an increase in one unit of compliance with the 
Table 3. Distribution of the Frequency Factors that triggers a relapse in the Mental Patients $(n=71)$

\begin{tabular}{|c|c|c|}
\hline Triggering Factor & $\mathbf{n}$ & $\%$ \\
\hline \multicolumn{3}{|l|}{ Patients compliance in taking medication } \\
\hline Irregular in taking medicine every day & 38 & 56 \\
\hline Do not want to take medicine at all & 28 & 39 \\
\hline Feel tired of taking medicine every day & 37 & 52 \\
\hline There are drugs around the house or patient's pocket & 41 & 58 \\
\hline Patients do not want to be reminded if they have not taken medication & 12 & 17 \\
\hline Patients do not want to be monitored when taking medication & 13 & 18 \\
\hline \multicolumn{3}{|l|}{ Utilization of health facilities } \\
\hline Rarely control to health facilities & 35 & 49 \\
\hline Do not want to go to control to the health facility & 17 & 24 \\
\hline \multicolumn{3}{|l|}{ Family support } \\
\hline Don't take the time to communicate with patients & 21 & 30 \\
\hline Do not give medication and do not supervise patients in taking medication & 13 & 18 \\
\hline Do not accompany the patient during control & 3 & 4 \\
\hline Do not pay attention to when patients must control & 9 & 13 \\
\hline Locking up patients at home & 22 & 31 \\
\hline \multicolumn{3}{|l|}{ Community Environment } \\
\hline Is considered disturbing the community & 27 & 38 \\
\hline Avoid when meeting patients & 30 & 42 \\
\hline Ridicule patients when meeting & 3 & 4 \\
\hline Talk about the patient's condition in front of the patient & 5 & 7 \\
\hline
\end{tabular}

Table 4. Logistic Regression Test Results ( $n=71)$

\begin{tabular}{lccc}
\hline Trigger Factor & B & p-value & Exp (B) \\
\hline Patients compliance in taking medication & $-2,610$ & 0,002 & 0,074 \\
Utilization of health facilities & 0,408 & 0,603 & 1,503 \\
Family support & $-2,736$ & 0,001 & 0,065 \\
Constant & 2,197 & 0,12 & 8,998 \\
\hline
\end{tabular}

medication will reduce the recurrence rate by 0.408 units. 5) The strength of the influence of the precipitating factors on the frequency of frequent recurrence is known from the value of Exp (B) obtained from the largest trigger factor (1), namely patient compliance with medication for 0.074, (2) family support at 0.065 and then ( 3 ) the utilization of health facilities at 1.503. The factor related to the utilization of the health facilities is a trigger factor with little influence. This is because the significance value is more than 0.05 . The researcher did not include the community environmental factors because the significant values per sub-factor have a value that is close to 1 .

\section{DISCUSSION}

A mental emergency is a condition that is characterized by a disturbance in a person's feelings, thoughts and behaviors that requires immediate attention and therapeutic action. This includes conditions related to anxiety, noise (agitation, aggression, violent behavior) and attempted suicide. This condition can occur outside or inside a health service building (Direktorat Bina Kesehatan Jiwa, 2015).

The patients who came to the Emergency ward had various types of mental illness. For each of them, there was a specific trigger factor which caused them to have their mental illness. The grouping of the mental disorders was based on the results of the 2013 Basic Health Research and divided into two parts, namely severe mental disorders (psychotic groups) and mild mental disorders which included all mental- emotional disorders in the form of panic, anxiety, disturbance and so on. Schizophrenia is included in the group of severe mental disorders (Yusuf et al., 2017).

From the data analysis above, the results show that there were some triggers factors for recurrence in the mental illness patients. Out of the 41 respondents (58\%), they broke the rules of drug compliance by throwing their drugs around the house or keeping the drugs in their pocket. This is in line with the study of Fitra (2013), who found that most of the patients had a low level of patient adherence. This is because there was a change in the patient's cognitive abilities which caused them to no longer be able to control themselves in all of their actions. They become unable to properly assess reality so then they are unable to take care of their own health. Therefore they need help from others(Fitra, M. S., Widodo, A., Zulaicha, 2013).

Furthermore, there were 35 respondents (49\%) who stated that they rarely controlled for the health facilities. According to the research conducted by Aji (2010), he also found that the more there was an absence of the health services as received by the respondents or the more difficult it was to get to the health services, the more likely that recurrence occurs. The better and more affordable the available health services, the greater the chance of preventing recurrence(Aji Wijaya \& Soewadi, 2010).

Moreover, a patient family tended to lock up patients at home $(31 \%)$ rather than take care of them well and full of attention. This result was in 
accordance with the research of Pratiwi, McEldowney, Richardson and He (2014) who found that the families always lock their patients in when the family members suffering from mental disorders have a relapse. The families always lock the patients in a room to prevent the patients from injuring the environment. They limit the patient movements to protect both the patients and their environment, and they fear the consequences of unexpected recurrence. Family behavior is based on a daily reality, attention paid to protecting the patients, and feeling anxious about the patient's condition. The way that the family members play a role in providing nursing care is needed by schizophrenics while at home. This shows that the higher the role of the family, the lower the recurrence(Pratiwi, Mceldowney, Richardson, \& He, 2014).

The other factor of recurrence of patients in the community is that most people avoid when meeting patients $(42 \%)$. The patient's family said that the people around them avoided them when meeting the patients because they feared that the patient would relapse when out socializing with the community. Some people avoided the patient due to their behavior in the community as the community often considered the patient's presence to be a nuisance. According to Yosep (2011), treatment is a process or method of healing a disorder caused by a source of interference. Therapeutic sources can be people in their environment or objects and activities that lead to healing. The psychological and physical environment is a condition that has a major influence on the healing process, especially for patients with mental disorders(Yosep, 2011).

The limitations of this research were 1.) That some of the families of the patients were not willing to be the subject of the research because of the condition of the patients who were experiencing recurrence in the Emergency Room of the Mental Hospital. They did not want to be interviewed, causing the researchers to look for other respondents who are willing. 2.) The researcher must interview and fill out the questionnaire instrument based on the patient's family response due to the limited time to care in the emergency room and the condition of the patient's family members who are anxious about the patient's condition, making it impossible for the patient's family to complete the questionnaire. 3.) Community environmental data obtained from family perceptions of people's attitudes would be better if it could be observed in the community around the patient.

\section{CONCLUSION}

Based on the research data that was collected, a conclusion can be drawn from the study which found that the characteristics of the patients who experienced a relapse in their mental disorders who come back to the Emergency Room of the Surakarta
Mental Hospital were mostly patients aged 25-35 years, of the male sex, who were last educated in high school and who didn't work. Most of the recurrence frequency of the mental health patients were in the category 'rarely recur' and the rest were in the category 'often recur'. The description of the trigger factors can be used to conclude that the biggest trigger factor was the patient's compliance in taking medication, which showed that $58 \%$ of them threw their drugs around the house or that they kept the drugs in their pocket. The other recurrence factors included family support, in which $31 \%$ of the family preferred to lock the patient up at home. Furthermore, the utilization of the health facilities was also a recurrence factor, in which $49 \%$ of the respondents rarely went to the health facilities. The last factor was environmental factors, in which most (42\%) were caused by a society that preferred to avoid meeting patients when they saw each other. This factor remained influential in recurrence even with a small value of influence.

\section{REFERENCES}

Aji Wijaya, \& Soewadi, H. (2010). Peran Pelayanan Kesehatan dalam Mencegah Terjadinya Kekambuhan pada Pasien Skizofrenia. Universitas Gadjah Mada.

Direktorat Bina Kesehatan Jiwa. (2015). Penatalaksanaan Kegawatdaruratan Psikiatri di Fasilitas Kesehatan Tingkat Primer (FKTP). Indonesian Ministry of Health.

Fitra, M. S., Widodo, A., Zulaicha, E. (2013). Hubungan Antara Faktor Kepatuhan Mengkonsumsi Obat, Dukungan Keluarga Dan Lingkungan Masyarakat Dengan Tingkat Kekambuhan Pasien Skizofrenia Di RSJD Surakarta. Universitas Muhammadiyah Surakarta.

Indonesian Ministry of Health. (2014). UndangUndang No. 18 Tahun 2014.

Indonesian Ministry of Health. (2016). Peran Keluarga Dukung Kesehatan Jiwa Masyarakat.

Kanel, K. (2015). A Guide to Crisis Intervention 5th Edition. USA: Cengage Learning.

Kelliat, B. A. (2011). Manajement Kasus Gangguan Jiwa CMHN (Intermediate Course). Jakarta: EGC.

Ministry of Health. (n.d.). Health Profile of Central Java Province.

Pratiwi, A., Mceldowney, R., Richardson, F., \& He, F. (2014). International Conference on Postgraduate Research 2014 (ICPR 2014), (December), 182192.

Surakarta Mental Hospital. (2017). Medical Record Surakarta Mental Hospital. Surakarta.

Yosep, I. (2011). Keperawatan Jiwa (Edisi Revisi). Bandung: PT Refika Aditama

Yusuf, A., PK, R. F., \& Nirhayati, H. E. (2017). Buku Ajar Keperawatan Kesehatan Jiwa. Jakarta: Salemba Medika. 